\title{
Meus aspectos favoritos do ensino de filosofia
}

\section{(São políticos? São educacionais? Ou são apenas filosóficos?)}

\author{
Hilan Bensusan
}

1. Amo o amadorismo. Sem amadorismo nada seria muito bem feito. Dizem que o Kennedy que foi presidente dizia que a política era importante demais para ser deixada nas mãos dos políticos. Já Lucy Lippard, que escreve sobre como a arte fabrica cultura todos os dias, parafraseia que a arte é importante demais para ser deixada em mãos de artistas. Então a filosofia é importante demais para ser deixada nas mãos dos filósofos. E, para completar o meu dicionário de palavras de ordem contra a profissionalização de partes das nossas cabeças, eu digo logo que a educação é importante demais para ser deixada nas mãos de educadores- $e$ ah, uma outra coisa, e vejo que meu dicionário de palavras de ordem não pode ser muito fininho: a ciência é importante demais para ser deixada nas mãos dos cientistas. Aprendemos desde criancinhas a deixar quase tudo nas mãos de uns poucos. E não deixamos apenas nas mãos de profissionais cadastrados: deixamos a política nas mãos dos grileiros, das corporações, dos exércitos; deixamos a arte nas mãos da propaganda, das firmas de entretenimento, dos pornógrafos; deixamos a ciência nas mãos dos capitães de indústria, dos governos ocidentais, das instituições militares; deixamos a educação nas mãos das novelas, das bancas de revistas, das canções de amor. A maioria das outras mãos fica sem nada dentro, nem política, nem arte, nem ciência, nem educação. E deixadas assim sem nada dentro, esperamos que vivam; ou seja, que façam alguma coisa durante o tempo em que não estão tendo que abaixar a cabeça. A filosofia é importante demais para ser deixada em algumas poucas mãos.

Mas o que fazemos quando não deixamos a filosofia nas mãos de filósofos? Quando a seguramos com a mão, toda na nossa mão, sem nos apoiar nas mãos que parecem ter um carimbo de profissionais, o nosso coração palpita. Nosso pensamento pode se encaminhar para muitas direções e para nenhum lado tem estrada asfaltada. É muito comum que assustemos. E então sentimos vergonha do que pensamos, medo de pensar alguma coisa errada, insegurança de que vamos por uma estrada que não vai dar em nada. Nosso pensamento está acostumado a ser tutelado. Como sentimos o risco de pensar, a vergonha, o medo e a insegurança conduzem nosso pensamento pela mão. Quando ensinamos filosofia podemos tutelar o pensamento de quem aprende. Eu, quando ensino filosofia, tenho sempre a alternativa ao alcance da mão de tutelar o pensamento de quem estuda: posso apresentar alguma resposta e nela por um carimbo-eu insisto nela, ela me parece uma boa maneira de pensar em alguma coisa e assim merece ser um ponto fixo no pensamento. Pontos fixos são confortáveis, tão confortáveis quanto uma parte da filosofia posta nas mãos de outras pessoas. Nos apressamos em direção a eles: teses, respostas, bulas para o pensamento. Também tenho a tentação de tutelar pensamento quando ofereço perguntas; as perguntas que valem 
a pena serem perguntadas. Na verdade, deixamos a filosofia nas mãos grandes $e$ aparentemente firmes dos filósofos canônicos quando deixamos que eles façam as perguntas.

A minha política quando ensino filosofia é a de tentar fazer com que quem a aprenda toque nela com as próprias mãos. Mas a sala de aula parece ter a geografia do pensamento tutelado-e os cursos de filosofia parecem sempre repetir o motto de que filosofia é para filósofos (às vezes também para filósofas): tornemse profissionais ou não toquem nela. Mas eu amo o amadorismo. Acho que se tivéssemos mais amadores, precisaríamos de menos profissionais. Acontece que pessoas amadoras não têm tempo, coragem, auto-estima para fazerem o que fazem as pessoas profissionais. Parece então que quem estuda não vai ter tempo, coragem e auto-estima para fazer muita filosofia a não ser que se tornem profissionais-pior ainda, já não têm tempo, coragem e auto-estima para fazerem muita filosofia a não ser se já se tornaram aprendizes de profissionais. Então minha política parece que se destrói a si mesma: ensino filosofia porque ela é importante demais para ficar na mão de profissionais da filosofia mas fazendo isto deixo a filosofia nas mãos dos tais profissionais. Calma. Talvez não seja assim tão grave. Há sempre uns buraquinhos, mesmo a sala de aula com a geografia do pensamento tutelado há janelas. Vocês sabem abrí-las?

2. Acho que a filosofia é uma maneira suave mas devastadora de não deixar as coisas como elas estão. Primeiro, a filosofia parece ter que ter uma obsessão em examinar-de preferência, ela tem que tentar examinar muitas coisas quase ao mesmo tempo. Ensinar filosofia é então saculejar os pontos fixos não-examinados. Aparece uma velha metáfora: pensar é movimentar; fazer pensar é saculejar. Vou abusar da velha metáfora: depois que saculejamos as coisas ficam mais livres, vão parar aonde não estavam. Um bom saculejo faz com que vejamos que coisas se movem e que coisas ficam fixas no chão. Quando pensamos (nesta nossa metáfora abusadíssima, quando saculejamos) somos livres; onde pensamos, sacudimos-o que está sendo pensado é o que não está sendo contornado. Contornar é uma coisa que aprendemos a fazer porque abaixamos a cabeça e a política não está em nossas mãos, a arte não está em nossas mãos, a ciência não está em nossas mãos, a educação não está em nossas mãos. Para quem não tem nada nas mãos, sobra apenas contornar-é o que fazemos quando topamos com uma pedra muito grande que não conseguimos mover. Aquilo que contornamos são os pontos fixos, aquilo que as outras instituições - $e$ as outras pessoas-colocaram na nossa cabeça. Ensinar filosofia deve ser uma coisa assim: denunciar. Denunciar é deixar explícitas as coisas que entram na cabeça das pessoas e que elas então tem que arranjar um jeito de contornar. Elas tem que aprender a viver com o que artistas dizem que é arte (e é belo, é invejável, é admirável), com o que cientistas dizem que é natural (e é compulsório, é inevitável, é além de toda liberdade) e com o que profissionais da informação dizem que os cientistas dizem que é natural, com o que educadores dizem que é inteligente e com o que os políticos dizem que é justo. No meio desta compartimentação da nossa vida mental em tantos quadradinhos, só resta às pessoas que são amadoras (e somos todas pessoas amadoras em quase 
tudo) contornar: temos que passar a vida em exercícios de contorcionismo. A filosofia devia ser uma recusa em contornar - a vida em que contornamos o que aparece pela frente ao invés de sacudir-não vale a pena. Ensinar filosofia devia ser ensinar a desaprender este contorcionismo.

Então penso logo no motto da entrada da Humboldt Universität em Berlin: os filósofos trataram de interpretar o mundo e trata-se de transformá-lo. Sempre acabo esbarrando neste slogan. Existe uma maneira de fazer filosofia (e de ensinála) que entende que a filosofia deixa as coisas como elas estão. De fato, é uma maneira de fazer filosofia e de ensiná-la que convém muito a profissionais. Deixar as coisas como estão, me parece, não é coisa para amadoras. Nunca entendi exatamente como a filosofia pode deixar as coisas como estão. Talvez concorde que se ela deixa as coisas como estão, não está sendo bem ensinada (ou já não foi bem aprendida). No contexto do motto da Humboldt, interpretar parece ser como contornar. E muitas vezes os filósofos contornam: ser profissional é também saber aceitar que certas coisas devem ser deixadas nas mãos de outros profissionais. Porém quando ensinamos a não ter que contornar, as pessoas pensam e se as pessoas realmente podem pensar, sacudir e não contornar, todas as paisagens das nossas instituições mentais ficam transformadas. Penso que certos modos de pensar-e de contornar o que pensamos como fatos-orientam a maneira como vivemos, e sobretudo a maneira como queremos viver. Quando buscamos a verdade, estamos sob a orientação do que nos satisfaz, do que nos deixa confortáveis. Penso que se colocamos a verdade de um lado e a nossa felicidade de outro perdemos ambas: contornamos uma idéia de felicidade qualquer que está conduzindo nossa busca da verdade, contornamos algumas supostas verdades orientando nossa busca da felicidade. Não vou falar mais disto agora. Tento ensinar que vale a pena pensar nisto. A filosofia, se é filosofia, transforma o modo como transformamos o mundo.

Segundo, a filosofia não entra em férias. Claro, as pessoas que fazem filosofia entram em férias não há praia, montanha ou quarto escuro onde não ficamos com os nossos pensamentos: e há liberdade, pode ser diferente. Há filosofia a ser feita quando há alguma vida mental. A filosofia, insinuava Wittgenstein, procura mostrar à mosca a saída da garrafa. Fora da garrafa, nada fica como está. Nossas moscas parecem andar de garrafas em garrafas-é como um labirinto onde contornamos todo o tempo. A libertação de uma garrafa não é para ninguém o fim do labirinto; esta imagem pode parecer claustrofóbica e vou deixar ela de lado. Se a filosofia for revolução, é revolução permanente-revolução sobre o que pode ser transformado por uma revolução. Ensinar filosofia torna a minha vida mais interessante quando as pessoas podem aprender a serem um pouco menos contorcionistas. Talvez ensine filosofia como meu grão de areia na tentativa de viver entre pessoas que não tenham rochedos que elas não conseguem mover dentro de suas cabeças. Uma comunidade de gentes com a cabeça leve assim—não me parece que haja um projeto político que me faça salivar mais. 
3. Penso que aprender filosofia deve ser a aquisição de alguma espécie de sabedoria. Acredito que a sabedoria é sobretudo um estado afetivo que depende de muitas coisas que pensamos, e dos muitos modos como agimos. A capacidade de pensar no seu próprio tom traz auto-estima. Algum Parmênides talvez dissesse que ensinar filosofia é ensinar coragem. Que talvez não haja outras coisas que possamos ensinar senão um punhado de emoções-ou seja, um punhado de disposições e motivações para tomar certos caminhos quando pensamos e agimos. Podemos ensinar quando se envergonhar, podemos ensinar quando admirar, quando ser indiferentes. Ensinar coragem não é ensinar um conjunto de princípios e nem um esquema de método para determinar que direção seguir. Parece ser alguma coisa como ensinar a sentir de certas maneiras e a não sentir de certas maneiras. Como sentimos determina até aonde vamos pensar e em que direção: o que fazer com os nossos pensamentos e o que fazer com o que não pensamos. Pensamentos são suprimidos pela vergonha, pelo medo, pela vontade de ser parte de algum grupo, pelo desespero em pensar de uma forma bem-vinda. Então ensinar filosofia é retirar rochedos que não deixam o pensamento passar. Estes rochedos não podemos tirar um a um, não podemos dinamitá-los todos, e nem podemos sequer olhar e ver todos eles, como vemos uma paisagem. Então sobra estimular quem aprende filosofia a reconhecer os rochedos $e$ a fazer com eles alguma coisa que não seja dar a volta. Mas cada pensamento é diferente de cada outro-cada ato de coragem dentro de nossas cabeças é diferente de cada ato de coragem dentro de nossas cabeças. E ainda assim, aprendemos alguma coisa quando aprendemos coragem.

Aprender coragem é muitas vezes aprender a conviver com um sentimento de vulnerabilidade. É difícil tentar dissolver os rochedos que todo mundo contorna sem alguma espécie de suporte emocional. Chamam de encorajamento: inculcar coragem; estimular quem tem está à beira de uma ação corajosa a não dar meiavolta. Muitas vezes penso que as salas de aulas, as paisagens do pensamento tutelar, não se prestam muito para aprender filosofia-parece que ali acontecem desencorajamentos facilmente. A política do encorajamento é uma política que conflita com algumas políticas emocionais bem consolidadas à nossa volta; sobretudo com a política do "você não é digno de nota (ou de atenção) até que prove em contrário". Encorajar é dar conforto para quem precisa pensar ao largo dos caminhos asfaltados; não acho que se possa fazer um caminho assim tendo que pagar um preço alto em termos de esforço mental para ter uma porção de auto-estima. $\mathrm{Na}$ sala de aula muitas vezes promovemos apenas o encorajamento seletivo: encorajamos quando as pessoas que estudam filosofia estão pensando em um caminho que interessa ao percurso que estamos fazendo. É claro que alguns percursos eles mesmos instruem porque mostram por exemplos como pensar através dos rochedos ao invés de contorná-los, como escolher caminhos que a primeira vista podem parecer pedregulhosos etc. E, no entanto, muitas vezes ensinamos filosofia mostrando $o$ percurso $e$ não as atitudes que trilharam $O$ percurso. Quando fico dizendo, e aqui estou fazendo isto em nível alto de abstração, que ensinar filosofia é ensinar algumas atitudes emocionais, faço isto já tendo desesperado de separar as atitudes emocionais dos conteúdos que as movem. Aprender atitudes já envolve aprender uns quantos conteúdos-certas desconfianças, certas alternativas de pensamento. A história da filosofia aparece 
vista assim como um conjunto de exemplos e de inspirações. Eu aponto para a história da filosofia (canônica) dentro da sala de aula tentando dizer sempre "por exemplo". Tenho a impressão de que na sala de aula a história da filosofia sempre é escutada como quem espera ver britadeiras asfaltando a estrada principal. Talvez para ensinar encorajamento eu tivesse que estar mais convencido-nos meus lábios mas também nos ouvidos de quem escuta na sala aula-de que se trata apenas de uma picada entre muitas.

Mas quem fala, quem pensa, quem escuta? Muitas vezes o conforto de quem pensa também é o silêncio de quem acompanha com os olhos. Por vezes o pensamento corajoso é um pensamento heróico; e rapidamente lapsa em direção à monofonia. Pensar também é enxergar o caminho que traçamos como uma picada-ainda que nos leve no caminho certo. Cultivar o pensamento encorajado é cultivar uma grande dose de polifonia: muitas picadas no mato. Aqui a sala de aula tem uma política que me parece muitas vezes devastadora: nós, quando ensinamos, atropelamos passos de estudantes e hierarquizamos caminhos. Eu sinto que estou hierarquizando caminhos freqüentemente na sala de aula: não porque não acredito em outros caminhos, mas não sei ainda aonde eles vão dar e parece que todos me olham como se eu estivesse em um mirante, como se eu tivesse uma visão panorâmica. Quando o nosso radar falha, optamos por estar do lado seguro e desencorajar - eis o encorajamento seletivo-um caminho que pode talvez dar no fim da picada. Quando faço isto, parece que amo minha profissão de controlador de radar mais do que amo os caminhos sendo trilhados. A sala de aula profissionaliza, a política do encorajamento é a política do amadorismo, faça você mesmo, nunca pare de pensar enquanto você acompanha os pensamentos das outras pessoas-com os carimbos dourados do cânone ou não-e assim você vai fazer alguma coisa mais além de colecionar pensamentos. $\mathrm{O}$ que fazer com as salas de aula? Talvez, no entanto, elas sejam encurtadoras de um caminho educacional, para não fazermos todo o caminho de pensamento com hesitação e coragem, com pessoalidade e com radicalidade, escolhemos o atalho da sala de aula. Desconfio que o atalho não compensa.

E agora, dá para amar o amadorismo, estimular que as pessoas encontrem modos de fazer filosofia bem e radicalmente e enfiar umas questões de filosofia nas provas de acesso à universidade? Eita. Não acredito em competição intelectual, não acredito em nenhum critério para restringir acesso. $\mathrm{E}$, no entanto, acho que a Realpolitik das cada questão das provas de acesso pode ter um peso na política do encorajamento. Elas podem estimular (da maneira errada, está claro, mas a ótima é às vezes inimiga da boa) atitudes de coragem e que não contornam os rochedos grandes. Muita coisa pode dar errado. Mas estas provas podem ser uma maneira (ruinzinha) de espalhar filosofia. Não parece ser uma boa idéia espalhar filosofia? 